ORIGINAL ARTICLE

\title{
Transient adrenocortical insufficiency of prematurity and systemic hypotension in very low birthweight infants
}

\author{
P C Ng, C H Lee, C W K Lam, K C Ma, T F Fok, I H S Chan, E Wong
}

Arch Dis Child Fetal Neonatal Ed 2004;89:F1 19-F126. doi: 10.1136/adc.2002.021972

\begin{abstract}
See end of article for authors' affiliations

Correspondence to: Professor $\mathrm{Ng}$, Department of Paediatrics, Level 6, Clinical Sciences Building, Prince of Wales Hospital, Shatin, NT, Hong Kong; pakcheungng@ cuhk.edu.hk
\end{abstract}

Accepted 17 March 2003

\begin{abstract}
Objectives: A proportion of preterm, very low birthweight (VLBW, $<1500 \mathrm{~g}$ ) infants may show inadequate adrenal response to stress in the immediate postnatal period. The human corticotrophin releasing hormone (hCRH) stimulation test was used to: $(a)$ determine the relation between pituitaryadrenal response and systemic blood pressure in these infants; (b) characterise the endocrinological features of transient adrenocortical insufficiency of prematurity (TAP).

Study design: A total of $226 \mathrm{hCRH}$ tests were performed on $137 \mathrm{VLBW}$ infants on day 7 and 14 of life in a tertiary neonatal centre.

Results: Basal, peak, and incremental rise in serum cortisol $\left(\Delta\right.$ Cort $\left._{0-30}\right)$ on day 7 were associated significantly with the lowest systolic, mean, and diastolic blood pressures recorded during the first two weeks of life $(r>0.25, p<0.005)$. These cortisol concentrations also correlated significantly but negatively with the maximum and total cumulative dose of dopamine $(r>-0.22, p<0.02)$, dobutamine $(r>-0.18, p<0.04)$, and adrenaline $(r>-0.26, p<0.004)$, total volume of crystalloid $(r>-0.22$, $\mathrm{p}<0.02)$, and duration of inotrope treatment $(r>-0.25, \mathrm{p}<0.006)$. Multivariate regression analysis of significant factors showed that the lowest systolic, mean, and diastolic blood pressures remained independently associated with serum cortisol (basal, peak, and $\Delta$ Corto-30) on day 7 . Hypotensive infants requiring inotropes (group 2) were significantly less mature and more sick than infants with normal blood pressure (group 1). The areas under the ACTH response curves were significantly greater in group 2 than in group 1 , on both day $7(p=0.004)$ and day $14(p=0.004)$. In contrast, the area under the cortisol response curve was significantly greater in group 1 than in group 2 on day 7 ( $p=0.001$ ), but there was no significant difference between the two groups on day 14. In addition, serum cortisol at the 50th centile in hypotensive infants had high specificity and positive predictive value $10.80-0.93$ and $0.81-0.89$ respectively) for predicting early neonatal hypotension.

Conclusions: This study characterises the fundamental endocrinological features of TAP: normal or exaggerated pituitary response; adrenocortical insufficiency; good recovery of adrenal function by day 14 of postnatal life. The results also provide the centiles of serum cortisol for hypotensive patients and infants with normal blood pressure, and show a significant relation between serum cortisol and blood pressure in VLBW infants.
\end{abstract}

$\mathrm{S}$ ystemic hypotension is a common complication of sick preterm infants. It is often associated with hypovolaemia, ${ }^{1}$ myocardial dysfunction, ${ }^{2}$ and deficient vascular tone. ${ }^{3}{ }^{4}$ Prompt and efficient treatment of neonatal hypotension is essential because persistent low blood pressure is associated with increased risk of intraventricular haemorrhage, periventricular leucomalacia, and long term neurodevelopmental sequelae in this vulnerable group of patients. ${ }^{5-}$

${ }^{7}$ Conventionally, volume replacement with either crystalloid (normal saline) or colloid (5\% albumin) solutions, and inotrope support with dopamine, dobutamine, and adrenaline are the treatments of choice. ${ }^{389}$ However, recent reports suggest that a significant proportion of very low birthweight (VLBW) infants suffer from refractory hypotension that is resistant to both volume expansion and high dose inotrope treatment. However, these patients respond readily to corticosteroids, hydrocortisone or dexamethasone, suggesting that an inadequate hypothalamic-pituitary-adrenal (HPA) response to stress may be a major cause. ${ }^{10-14}$ Thus far, it has not been possible to delineate the exact hormonal pattern during the hypotensive episode and to be certain whether such responses represent genuine endocrine insufficiency or low but appropriate circulating concentrations of hormone for these gestations. This prospective study therefore aimed to investigate the relation between pituitary-adrenal response and systemic blood pressure using the human corticotrophin releasing hormone (hCRH) stimulation test. The study is part of a series of investigations to assess the association between early pituitary-adrenal response and perinatal factors or outcomes in VLBW infants. ${ }^{15}$ It was also designed to characterise the endocrinological features of the phenomenon of transient adrenocortical insufficiency of prematurity (TAP) by identifying the site of hormonal dysfunction in the HPA axis and the timing of pituitary-adrenal recovery by performing two hCRH tests in quick succession on day 7 and 14. A knowledge of the underlying pathophysiology of early neonatal hypotension in these infants would help to define the most appropriate and effective treatment at an early stage in the disease process.

\section{PATIENTS AND METHODS}

Study population

A total of 137 VLBW infants were enrolled prospectively into the study. Inclusion criteria were: gestational age less than

Abbreviations: $\mathrm{ACTH}$, adrenocorticotrophin; $\mathrm{hCRH}$, corticotrophin releasing hormone; HFOV, high frequency oscillatory ventilation; HPA, hypothalamic-pituitary-adrenal; IPPV, intermittent positive pressure ventilation; TAP, transient adrenocortical insufficiency of prematurity; VLBW, very low birthweight 
32 weeks; birth weight less than 1500 g; no postnatal systemic or inhaled corticosteroid treatment before the hCRH test; possession of an indwelling arterial cannulae for continuous monitoring of blood pressure and blood sampling on day 7 of life. A second hCRH test was performed if the arterial cannulae remained in situ on day 14. Infants were excluded if they had concurrent hypoglycaemia, systemic infection, necrotising enterocolitis, or major surgery in the preceding week. The use of antenatal corticosteroids did not preclude the infants from receiving the hCRH test, as most preterm patients would have received such treatment to enhance lung maturity. Each antenatal course consisted of two doses of $10 \mathrm{mg}$ dexamethasone (dexamethasone sodium phosphate; Weiner Pharma, Gmbh, Rastatt, Germany), given 12 hours apart. Infants requiring intubation and positive pressure ventilation received a standard course of surfactant (Surventa; Abbott Laboratories, North Chicago, Illinois, USA; two doses of $4 \mathrm{ml} / \mathrm{kg}$, given 12 hours apart) as rescue treatment for respiratory distress syndrome. All infants $\leqslant 1250 \mathrm{~g}$ were given low dose indomethacin (Indocin; Merck \& Co, West Point, Philadelphia, USA; $0.1 \mathrm{mg} / \mathrm{kg}$ intravenously within six hours of birth and then every 24 hours for two further doses) to prevent intraventricular haemorrhage. ${ }^{16}$ Gestation was assessed from the mother's last menstrual period, early ultrasound dating, and the new Ballard score after birth. ${ }^{17}$

\section{Management of hypotension in VLBW infants}

As there is no reference standard of "normal" blood pressure for preterm infants, the commonly used guidelines proposed by the Joint Working Group of the British Association of Perinatal Medicine and the Research Unit of the Royal College of Physicians (UK) ${ }^{18}$ have been adopted for use in our neonatal unit. Hypotension is defined as a mean arterial blood pressure lower than the numerical value of the gestational age of an infant in completed weeks. This simple definition was further supported by a subsequent study, which found similar results. ${ }^{19}$ VLBW infants admitted for intensive care and requiring regular monitoring of blood pressure, blood gases, or biochemical indices would receive an indwelling arterial line. It is the policy of the neonatal unit to retain this line until routine monitoring of vital signs and daily blood sampling have ceased.

Strict guidelines were provided for attending neonatologists on the use of volume expanders and inotropes for treatment of hypotension. Three doses of normal saline $(10 \mathrm{ml} / \mathrm{kg} \times 3)$ were given initially to correct hypovolaemia. Blood products such as packed cells, fresh frozen plasma, and platelets were not prescribed routinely and were used only as clinically indicated for treatment of severe anaemia, coagulopathy, and thrombocytopenia. If volume expansion was unsuccessful in maintaining a desirable blood pressure, inotropes were added. Infusion of dopamine and/or dobutamine was started at a rate of $5-10 \mu \mathrm{g} / \mathrm{kg} / \mathrm{min}$ depending on the patient's condition, and the dose increased by $5 \mu \mathrm{g} / \mathrm{kg} /$ min every 30 minutes until an adequate blood pressure was achieved. However, if $20 \mu \mathrm{g} / \mathrm{kg} / \mathrm{min}$ dopamine and dobutamine failed to maintain an acceptable mean arterial blood pressure, adrenaline infusion at a rate of $0.2 \mu \mathrm{g} / \mathrm{kg} / \mathrm{min}$ was started. The dose was increased in a stepwise fashion at a rate of $0.2 \mu \mathrm{g} / \mathrm{kg} / \mathrm{min}$ every 30 minutes until a normal blood pressure was attained. During the escalating or weaning phase of inotropic treatment, further doses of volume expander were administered whenever there were indications of intravascular volume deficiency. Echocardiography was performed in infants with an audible murmur at 72 hours of life and in hypotensive patients requiring dopamine infusion greater than $10 \mu \mathrm{g} / \mathrm{kg} / \mathrm{min}$. The use of dobutamine was usually reserved for patients with poor cardiac contractility, defined as fractional shortening $<28 \%$ or ejection fraction $<50 \%$. None of the patients in this study received antihypertensive drugs during the first two weeks of life.

\section{hCRH test and hormone assays}

We chose to perform the hCRH tests on day 7 and 14 of life, for reasons discussed previously..$^{20}$ All tests were performed between 08:00 $\mathrm{h}$ and 10:00 h. Each vial $(100 \mu \mathrm{g})$ of synthetic hCRH (Ferring, Arzneimittal, Wittland, Germany) was reconstituted with the standard diluent provided, and then further diluted with sterile water to obtain a concentration of $2 \mu \mathrm{g} / \mathrm{ml}$. Blood samples $(0.5 \mathrm{ml})$ were obtained from the indwelling arterial line for measurement of the basal (0 min) plasma adrenocorticotrophin (ACTH) and serum cortisol concentrations before hCRH $(1 \mu \mathrm{g} / \mathrm{kg})$ was administered by bolus intravenous injection. Three further sets of blood samples were taken 15, 30, and 60 minutes after the hCRH injection. The blood samples were immersed immediately in ice and transported to the laboratory. The plasma ACTH and serum cortisol concentrations were measured by double antibody radioimmunoassay and solid phase radioimmunoassay respectively. Processing of blood samples and details of hormone measurement have been described previously. ${ }^{20}$ The ACTH double antibody radioimmunoassay has $0 \%$ crossreactivity with human ACTH fragments (ACTH 1-24, 11-24, $18-39$, and $1-10)$ and other related hormones ( $\alpha$-melanocyte stimulating hormone, $\beta$-melanocyte stimulating hormone, $\beta$ lipotrophic pituitary hormone, and $\beta$-endorphin) even when these potential cross reactants are present at very high concentrations (1100-22000 pmol/l). The interassay coefficients of variation of the ACTH assay were $4.4 \%$ and $3.7 \%$ at 10.1 and $79.3 \mathrm{pmol} / \mathrm{l}$ respectively; those of the cortisol assay were $9.1 \%, 4.2 \%$, and $4 \%$ at 159,461 , and $1260 \mathrm{nmol} / \mathrm{l}$ respectively, with an accuracy better than the \pm 0.5 allowable limits recommended by the monthly Royal College of Pathologists of Australia quality assurance programme. ${ }^{20}$

\section{Data collection}

Table 1 presents the clinical characteristics of the infants. Data on blood pressure measurements, use of inotropes and volume expanders, including the lowest systolic, mean, and diastolic blood pressure registered during the first 14 days of life, the blood pressures recorded immediately before the hCRH tests on day 7 and 14 , the maximum dose $(\mu \mathrm{g} / \mathrm{kg} / \mathrm{min})$ and the total cumulative dose of dopamine, dobutamine, and adrenaline $(\mu \mathrm{g} / \mathrm{kg})$ administered during the first 14 days, and the total volume of crystalloid $(\mathrm{ml} / \mathrm{kg}$ ) used for treatment of hypotension, were calculated and documented during the study period. The arterial blood pressure was measured continuously through indwelling peripheral arterial lines or umbilical arterial catheters. The blood pressure data were captured by the automatic management system of the monitors, and the accuracy of the data was cross checked manually with the clinical findings in the case records.

\section{Ethical approval}

Ethical approval for the study was obtained from the clinical research ethics committee of the Chinese University of Hong Kong. Written informed parental consent was obtained for each case before the start of the test.

\section{Statistical analysis}

Spearman's correlation was used to assess the relation between the hormone concentrations (basal and peak plasma ACTH and serum cortisol concentrations, and the incremental rise in hormone concentration-that is, the difference in plasma ACTH concentrations between 0 and $15 \mathrm{~min}$ $\left(\triangle \mathrm{ACTH}_{0-15}\right)$ and serum cortisol concentrations between 0 and $30 \mathrm{~min}\left(\Delta\right.$ Cort $\left.\left._{0-30}\right)\right)$ and $(a)$ the clinical characteristics of 
Table 1 Clinical characteristics of the study population

\begin{tabular}{|c|c|c|}
\hline & Group 1 ( $n=59$ ) & Group 2 ( $n=78$ ) \\
\hline Gestational age (weeks) & $29.4(27.3-31.6)$ & $27.9(26.1-29.5)^{\star *}$ \\
\hline Birth weight (g) & 1235 (1045-1360) & $1035(777-1200)^{* *}$ \\
\hline Sex (male/female) & 23 (39\%): 36 (61\%) & 49 (63\%): $29(37 \%)^{*}$ \\
\hline CRIB score & $1(1-2)$ & $4(2-7)^{* *}$ \\
\hline $\begin{array}{l}\text { Mode of delivery } \\
\text { (vaginal:caesarean section) }\end{array}$ & $23(39 \%): 36$ (61\%) & $35(45 \%): 43(55 \%)$ \\
\hline \multicolumn{3}{|l|}{ Apgar scores } \\
\hline $1 \mathrm{~min}$ & $7(6-8)$ & $6(4-7)^{*}$ \\
\hline $5 \mathrm{~min}$ & $9(8-9)$ & $8(7-9)^{*}$ \\
\hline Inborn/outborn & $57(97 \%): 2(3 \%)$ & $76(97 \%): 2(3 \%)$ \\
\hline Membrane ruptured $>24 \mathrm{~h}$ & $13(22 \%)$ & $15(19 \%)$ \\
\hline Maternal pre-eclampsia & $9(15 \%)$ & $9(12 \%)$ \\
\hline Antepartum haemorrhage & $7(12 \%)$ & $15(19 \%)$ \\
\hline $\begin{array}{l}\text { Doses of antenatal } \\
\text { corticosteroids }\end{array}$ & $2(1-4)$ & $1(1-3)^{*}$ \\
\hline $\begin{array}{l}\text { Time between the last dose } \\
\text { of antenatal corticosteroids } \\
\text { and delivery (h) }\end{array}$ & $19(5-51)$ & $19(4-52)$ \\
\hline $\begin{array}{l}\text { Duration of mechanical } \\
\text { ventilation (days) }\end{array}$ & $10(4-29)$ & $31(16-44)^{* *}$ \\
\hline $\begin{array}{l}\text { Duration of } \mathrm{O}_{2} \text { dependency } \\
\text { (days) }\end{array}$ & $9(1-26)$ & $18(11-35)^{\star *}$ \\
\hline $\begin{array}{l}\text { Duration of hospital stay } \\
\text { (days) }\end{array}$ & $86(65-107)$ & $92(70-124)$ \\
\hline \multicolumn{3}{|l|}{$\begin{array}{l}\text { Mean arterial blood pressure } \\
(\mathrm{mm} \mathrm{Hg})\end{array}$} \\
\hline Lowest (first 14 days) & $28(31-34)$ & $23(21-26)^{* *}$ \\
\hline Day 7 & $48(42-54)$ & $38(33-45)^{* *}$ \\
\hline Day 14 & $45(42-51)$ & $43(38-49)$ \\
\hline Volume expander $(\mathrm{ml} / \mathrm{kg})$ & $33(14-68)$ & $76(50-110)^{* *}$ \\
\hline Age started on inotropes (h) & - & $7(4-12)$ \\
\hline $\begin{array}{l}\text { Duration of inotrope } \\
\text { support (h) }\end{array}$ & - & $112(65-177)$ \\
\hline \multicolumn{3}{|l|}{ Dopamine } \\
\hline $\begin{array}{l}\text { Maximum dose }(\mu \mathrm{g} / \mathrm{kg} / \\
\min )\end{array}$ & - & $20(10-30)$ \\
\hline $\begin{array}{l}\text { Total cumulative dose } \\
(\mu \mathrm{g} / \mathrm{kg})\end{array}$ & - & $\begin{array}{l}75990(31688- \\
138325)\end{array}$ \\
\hline \multicolumn{3}{|c|}{$\begin{array}{l}\text { Results are median (interquartile range) or number of cases (percentage). } \\
\text { Group } 1 \text {, infants not requiring inotrope treatment; group } 2 \text {, infants } \\
\text { requiring inotrope treatment. } \\
\text { * } p<0.05 \text { and ** } p<0.001 \text { compared with group } 1 . \\
\text { CRIB, Clinical risk index for babies. }\end{array}$} \\
\hline
\end{tabular}

the infants (table 1$),(b)$ the lowest systolic, mean, and diastolic blood pressures recorded during the first 2 weeks of life, and $(c)$ the blood pressures recorded immediately before the hCRH tests on days 7 and 14. Significant indices or measurements $(\mathrm{p}<0.05)$ associated with plasma ACTH or serum cortisol were further subjected to multivariate regression analysis using a forward stepwise selection strategy. The process added the most significant variable to the model at each step, and continued until no further significant variables were identified. As some of the independent variables assessed may be highly intercorrelated and could cause multicollinearity problems in the analysis, such variables were entered separately into the model. Multicollinearity was defined as condition index above the value of 10. When two or more potential variables had similar $\mathrm{p}$ values, the variable considered clinically more important was chosen for the final model. The Mann-Whitney $U$ test and $\chi^{2}$ test were used to compare the clinical characteristics of hypotensive infants who received inotrope treatment (group 2) and infants with normal blood pressure who did not (group 1). The areas under the ACTH and cortisol response curves were also compared between the two groups. These statistical tests were performed by SPSS for Windows (Release 11.0, SPSS Inc, Chicago, Illinois, USA), and the statistical analysis was performed on raw or logarithmically transformed data where appropriate to correct the skewness of the results.

The multilevel models were used to construct the centile tables of serum cortisol for group 1 and group 2 infants on days 7 and 14. Serum cortisol concentrations that were 3 SD above or below the mean level for a particular time point were considered outliers and excluded from the final analysis. The models were fitted by the method of restricted iterative generalised least square algorithm of MLn for Windows software package (version 2.0; Institute of Education, University of London, UK). The centile derived from the MLn represented the 50th centile under the normality assumption. Other centiles were obtained as mean $\pm \mathrm{zSD}$, where $\mathrm{z}=-1.88,-1.28,1.28$, and 1.88 for the $3 \mathrm{rd}$, 10th, 90th, and 97th centiles respectively.

\section{RESULTS}

A total of 226 hCRH tests were performed on 137 preterm VLBW infants on days 7 and 14 of postnatal age. Figure 1 shows the recruitment process and the number of infants studied at the two time points. The study was carried out over a 50 month period during the mid and late 1990s. The preliminary ACTH and cortisol results of this cohort have been compiled to provide a reference range for the hCRH test in VLBW infants. ${ }^{15}$ The data on the relation between hormones of the HPA axis and blood pressure, inotropes, or volume expanders have not been reported previously.

\section{Overall analysis}

\section{Hormones and blood pressure}

When the results of the study population were pooled and analysed, both basal and peak serum cortisol and $\Delta$ Cort $_{0-30}$ on day 7 were significantly associated with $(a)$ the lowest systolic, mean, and diastolic blood pressures recorded during the first 14 days of life $(r>0.25, \mathrm{p}<0.005)$, and $(b)$ the blood pressures measured immediately before the first hCRH test on day $7(r>0.30, \mathrm{p}<0.001)$. In contrast, plasma ACTH on days 7 and 14 and serum cortisol on day 14 did not

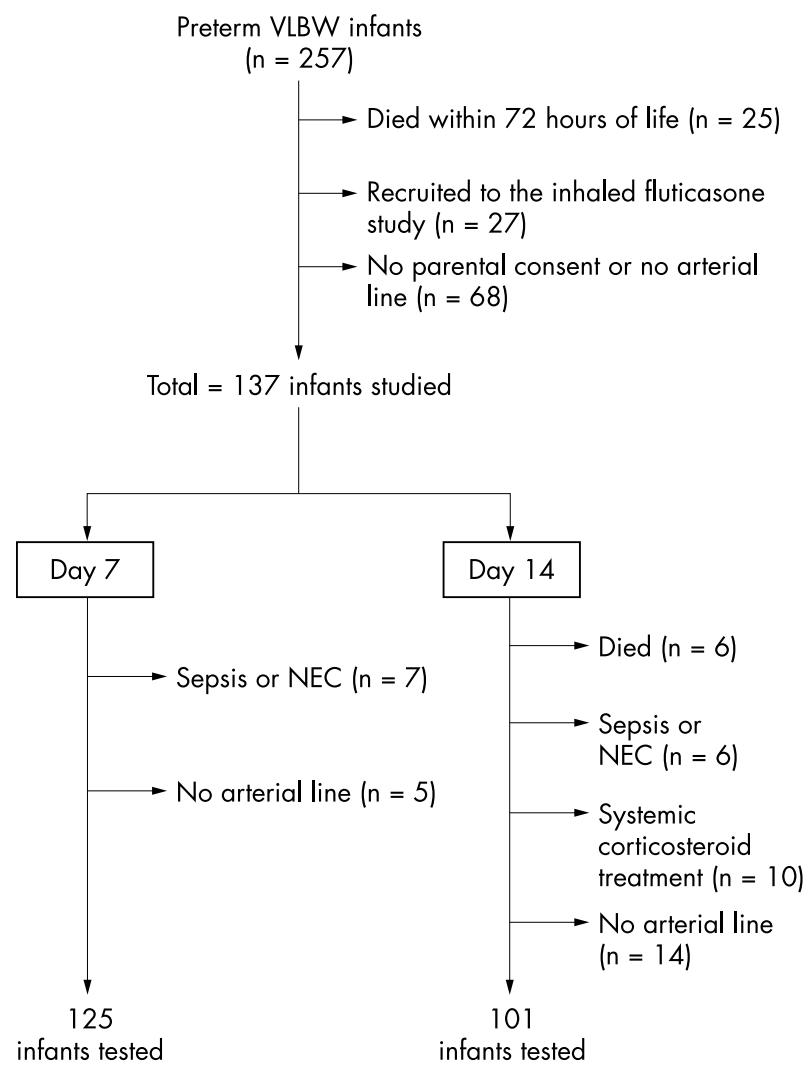

Figure 1 Patient recruitment process of the study. NEC, Necrotising enterocolitis. 
correlate consistently with the lowest blood pressure or the blood pressure taken immediately before the hCRH tests.

\section{Hormones and inotropes or volume expanders}

Serum cortisol on day 7 (basal, peak, and $\Delta$ Cort $_{0-30}$ ) correlated negatively with the maximum and total cumulative dose of dopamine $(r>-0.22, \mathrm{p}<0.02)$, dobutamine $(r>-0.18, \mathrm{p}<0.04)$, and adrenaline $(r>-0.26, \mathrm{p}<0.004)$, total volume of crystalloid $(r>-0.22, \mathrm{p}<0.02)$, and duration of inotrope treatment $(r>-0.25, \mathrm{p}<0.006)$. In contrast, plasma ACTH on days 7 (peak levels and $\triangle \mathrm{ACTH}_{0-}$ 15) and 14 (basal and peak levels) were significantly and positively associated with the maximum and total cumulative dose of dopamine $(r>0.24, \mathrm{p}<0.03)$ and dobutamine $(r>0.20, \mathrm{p}<0.05)$, total volume of crystalloid $(r>0.28$, $\mathrm{p}<0.02)$, and duration of inotrope treatment $(r>0.26$, $\mathrm{p}<0.02)$

\section{Hormones and clinical parameters}

Serum cortisol on day 7 (basal, peak, and $\Delta$ Cort $_{0-30}$ ) correlated negatively with the clinical risk index for babies (CRIB) score $(r>-0.19, \mathrm{p}<0.05)$, duration of mechanical ventilation $(r>-0.21, \mathrm{p}<0.02)$, oxygen supplementation $(r>-0.19, \mathrm{p}<0.04)$, and hospital stay $(r=-0.25$, $\mathrm{p}=0.006$; peak levels only). This negative relation (basal and peak levels) was reversed by day $14(r>0.28, \mathrm{p}<0.01$; $r>0.21, \mathrm{p}<0.05$ and $r>0.27, \mathrm{p}<0.01$ for CRIB score, duration of mechanical ventilation, and oxygen supplementation respectively).

In addition, our previous study on the same cohort of patients suggested that two other major factors, the mode of mechanical ventilation (intermittent positive pressure ventilation (IPPV)/high frequency oscillatory ventilation (HFOV)) and the number of doses of antenatal corticosteroids significantly influenced serum cortisol concentrations on day 7. ${ }^{15}$ There was, however, no significant association between plasma ACTH or serum cortisol at any stage and gestational age or birth weight.

\section{Multivariate analysis}

Significant factors of the univariate analysis $(\mathrm{p}<0.05)$, including CRIB score, duration of mechanical ventilation and oxygen supplementation, mode of mechanical ventilation (IPPV/HFOV), number of doses of antenatal corticosteroids, the lowest systolic, mean, and diastolic blood pressures recorded during the first 14 days of life, the maximum and total cumulative doses of inotropes, total volume of crystalloid, and duration of inotropic support, were subjected to the multivariate forward stepwise linear regression model using basal and peak serum cortisol and $\Delta$ Cort $_{0-30}$ as dependent variables. The results suggest that the mode of mechanical ventilation (IPPV/HFOV), antenatal corticosteroid usage, and the lowest systolic, mean, and diastolic blood pressures were independently associated with serum cortisol (basal, peak, and $\Delta$ Cort ${ }_{0-30}$ ) on day 7 (table 2).

\section{Group 1 v group 2}

Table 1 summarises the clinical characteristics of hypotensive infants who received inotropes (group 2) and those who did not (group 1). Although group 2 infants were significantly less mature and more sick than infants of group 1 (table 1), the ACTH response, represented by the areas under the curves of the hCRH test, were significantly greater in group 2 than in group 1 , on both day 7 $(\mathrm{p}=0.004)$ and day $14(\mathrm{p}=0.004$; fig 2$)$. In contrast, the area under the cortisol response curve was significantly greater in group 1 than in group 2 on day 7 ( $p=0.001$; fig 3 ). There was, however, no significant difference between the two groups in cortisol response on day $14(p=0.154)$.

Table 2 Results of the multivariate regression analysis

\begin{tabular}{|c|c|c|c|c|c|c|c|c|c|c|c|c|}
\hline & \multicolumn{4}{|c|}{ Basal cortisol } & \multicolumn{4}{|c|}{ Peak cortisol } & \multicolumn{4}{|l|}{$\Delta$ Cort $_{0-30}$} \\
\hline & Coefficient & SE & $p$ Values & $R^{2}(\%)$ & Coefficient & SE & $\mathrm{p}$ Values & $R^{2}(\%)$ & Coefficient & SE & $\mathrm{p}$ Values & $R^{2}$ (\%) \\
\hline $\begin{array}{l}\text { Lowest systolic } \\
\text { pressure }\end{array}$ & 0.016 & 0.010 & 0.115 & 22.6 & 0.010 & 0.004 & 0.011 & 80.2 & 5.023 & 1.804 & 0.006 & 18.4 \\
\hline $\begin{array}{l}\text { No antenatal } \\
\text { dexamethasone }\end{array}$ & -0.461 & 0.178 & $<0.001$ & & -0.157 & 0.066 & 0.019 & & -63.345 & 31.868 & 0.049 & \\
\hline $\begin{array}{l}\text { Antenatal dexamethasone } \\
\text { (1-2 doses) }\end{array}$ & -0.577 & 0.204 & 0.006 & & -0.141 & 0.076 & 0.067 & & -65.182 & 36.712 & 0.078 & \\
\hline $\begin{array}{l}\text { Mode of mechanical } \\
\text { ventilation (IPPV/HFOV) }\end{array}$ & -0.654 & 0.164 & $<0.001$ & & -0.165 & 0.063 & 0.010 & & -82.502 & 30.495 & 0.008 & \\
\hline $\begin{array}{l}\text { (Ln) Basal cortisol } \\
\text { (day 7) }\end{array}$ & - & - & - & & 0.543 & 0.033 & $<0.001$ & & -34.035 & 16.026 & 0.036 & \\
\hline Lowest mean pressure & -0.035 & 0.014 & 0.011 & 25.2 & 0.015 & 0.005 & 0.003 & 80.6 & 8.519 & 2.852 & 0.003 & 19.1 \\
\hline $\begin{array}{l}\text { No antenatal } \\
\text { dexamethasone }\end{array}$ & -0.452 & 0.175 & 0.011 & & -0.155 & 0.065 & 0.019 & & -56.775 & 31.581 & 0.075 & \\
\hline $\begin{array}{l}\text { Antenatal dexamethasone } \\
\text { (1-2 doses) }\end{array}$ & -0.572 & 0.200 & 0.005 & & -0.141 & 0.075 & 0.062 & & -62.171 & 36.443 & 0.091 & \\
\hline $\begin{array}{l}\text { Mode of mechanical } \\
\text { ventilation } \\
\text { (IPPV/HFOV) }\end{array}$ & -0.555 & 0.167 & 0.001 & & -0.150 & 0.063 & 0.020 & & -78.432 & 30.595 & 0.012 & \\
\hline $\begin{array}{l}\text { (Ln) Basal cortisol } \\
\text { (day 7) }\end{array}$ & - & - & - & & 0.532 & 0.033 & $<0.001$ & & -38.503 & 16.201 & 0.019 & \\
\hline $\begin{array}{l}\text { Lowest diastolic } \\
\text { pressure }\end{array}$ & 0.040 & 0.016 & 0.013 & 25.0 & 0.021 & 0.006 & $<0.001$ & 81.2 & 6.479 & 2.512 & 0.011 & 17.1 \\
\hline $\begin{array}{l}\text { No antenatal } \\
\text { dexamethasone }\end{array}$ & -0.429 & 0.175 & 0.016 & & -0.145 & 0.064 & 0.025 & & -60.819 & 31.946 & 0.059 & \\
\hline $\begin{array}{l}\text { Antenatal dexamethasone } \\
\text { (1-2 doses) }\end{array}$ & -0.560 & 0.201 & 0.006 & & -0.138 & 0.074 & 0.063 & & -63.598 & 36.843 & 0.087 & \\
\hline $\begin{array}{l}\text { Mode of mechanical } \\
\text { ventilation } \\
\text { (IPPV/HFOV) }\end{array}$ & -0.564 & 0.166 & 0.001 & & -0.137 & 0.062 & 0.029 & & -82.398 & 31.010 & 0.009 & \\
\hline $\begin{array}{l}\text { (Ln) Basal cortisol } \\
\text { (day 7) }\end{array}$ & - & - & - & & 0.529 & 0.033 & $<0.001$ & & -37.314 & 16.368 & 0.024 & \\
\hline
\end{tabular}

$\mathrm{SE}$, standard error; IPPV, intermittent positive pressure ventilation; HFOV, high frequency oscillatory ventilation. 
- Group 1 (no inotrope)

- Group 2 (with inotropes)

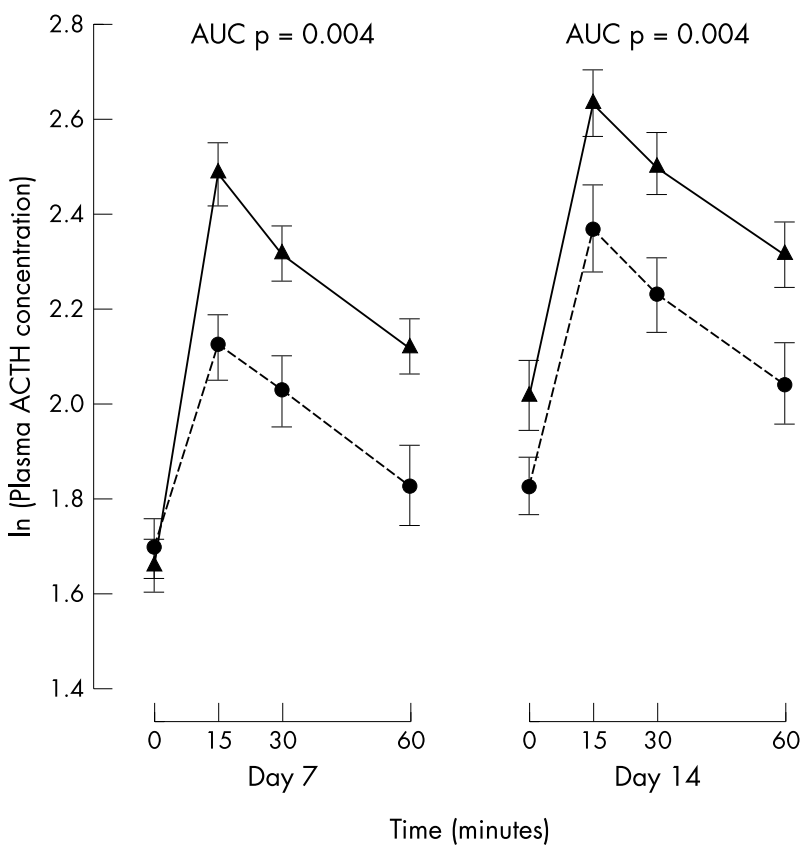

Figure 2 Adrenocorticotrophin (ACTH) response of the human corticotrophin releasing hormone test on days 7 and 14 in very low birthweight infants with relatively normal blood pressure (group 1) and in hypotensive infants requiring inotropic support (group 2). The values are mean (SEM). The area under the curve (AUC) is significantly greater in group 2 than in group 1 , on both day $7(p=0.004)$ and 14 $(p=0.004)$.

Tables 3 and 4 provide the centile distribution of serum cortisol of group 1 and group 2 infants on days 7 and 14 respectively. Table 5 compares the diagnostic utilities, including sensitivity, specificity, and positive and negative predictive values, by using different centiles of serum cortisol on day 7 as cut off values for diagnosing hypotension in VLBW infants.

\section{DISCUSSION}

The hCRH test was chosen to evaluate the pituitary and adrenal function in VLBW infants because it is safe, reproducible, and capable of producing a consistent pituitary-adrenal response in preterm infants, similar to that observed in older children and adults. ${ }^{20}$ This stimulation test has also been proven to be superior in showing a
- Group 1 (no inotrope)

- Group 2 (with inotropes)

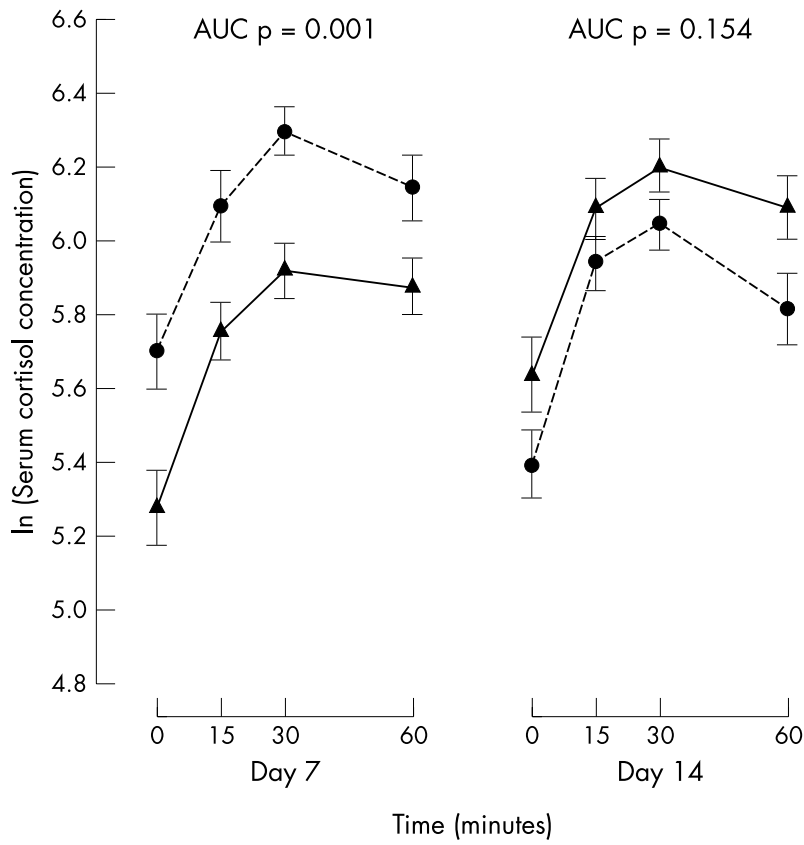

Figure 3 Cortisol response of the human corticotrophin releasing hormone test on day 7 and 14 in very low birthweight infants with relatively normal blood pressure (group 1) and in hypotensive infants requiring inotropic support (group 2). The values are mean (SEM). The area under the curve (AUC) is significantly greater in group 1 than in group 2 on day $7(p=0.001)$.

milder degree of adrenal insufficiency compared with other HPA axis stimulation tests. ${ }^{21}$ Yoder and coworkers ${ }^{22}$ recently described the association of impaired urinary cortisol excretion with early cardiovascular dysfunction in premature baboons, and observed a significant improvement in cardiovascular function 4-6 hours after hydrocortisone replacement. In humans, a few small case series studies have reported relatively low serum cortisol in preterm as well as term hypotensive newborns, ${ }^{11} 14^{23}$ and a cohort study indicated that serum cortisol correlated inversely with the use of surfactant and inotropes in sick preterm infants. ${ }^{24}$ However, a randomised control trial involving a small cohort of VLBW infants $(n=40)$ failed to confirm the benefit of hydrocortisone over dopamine for routine treatment of hypotension or an association between circulating cortisol concentration and the maximum dopamine dose. ${ }^{25}$

Table 3 Centile table of serum cortisol concentrations at day 7 in preterm infants with normal blood pressure (group 1) and hypotensive infants requiring inotropic support (group 2)

\begin{tabular}{|c|c|c|c|c|c|c|c|c|}
\hline \multirow[b]{2}{*}{ Centile } & \multicolumn{4}{|c|}{ Group $1(n=54)$} & \multicolumn{4}{|c|}{ Group $2(n=71)$} \\
\hline & $0 \mathrm{~min}$ & $15 \mathrm{~min}$ & $30 \mathrm{~min}$ & $60 \mathrm{~min}$ & $0 \min$ & $15 \min$ & $30 \mathrm{~min}$ & $60 \mathrm{~min}$ \\
\hline $3 \mathrm{rd}$ & 99 & 192 & 270 & 223 & 43 & 86 & 131 & 117 \\
\hline 10th & 142 & 254 & 340 & 286 & 70 & 128 & 185 & 165 \\
\hline 25 th & 206 & 338 & 431 & 366 & 115 & 191 & 261 & 235 \\
\hline 50th & 311 & 464 & 561 & 483 & 198 & 299 & 384 & 347 \\
\hline 75 th & 470 & 637 & 730 & 637 & 343 & 467 & 564 & 514 \\
\hline 90th & 680 & 848 & 925 & 817 & 560 & 697 & 797 & 730 \\
\hline 97th & 979 & 1123 & 1168 & 1044 & 909 & 1034 & 1121 & 1033 \\
\hline
\end{tabular}


Table 4 Centile table of serum cortisol concentrations at day 14 in preterm infants with normal blood pressure (group 1) and hypotensive infants requiring inotropic support (group 2)

\begin{tabular}{|c|c|c|c|c|c|c|c|c|}
\hline \multirow[b]{2}{*}{ Centile } & \multicolumn{4}{|c|}{ Group $1(n=51)$} & \multicolumn{4}{|c|}{ Group $2(n=50)$} \\
\hline & $0 \mathrm{~min}$ & $15 \mathrm{~min}$ & $30 \mathrm{~min}$ & $60 \mathrm{~min}$ & $0 \mathrm{~min}$ & $15 \mathrm{~min}$ & $30 \mathrm{~min}$ & $60 \mathrm{~min}$ \\
\hline $3 r d$ & 77 & 149 & 180 & 128 & 88 & 148 & 220 & 181 \\
\hline 10th & 102 & 195 & 236 & 175 & 120 & 205 & 286 & 241 \\
\hline 25th & 146 & 256 & 310 & 240 & 178 & 287 & 374 & 322 \\
\hline 50 th & 219 & 347 & 420 & 340 & 279 & 416 & 503 & 446 \\
\hline 75 th & 329 & 470 & 569 & 483 & 435 & 603 & 677 & 616 \\
\hline 90th & 473 & 618 & 748 & 663 & 649 & 841 & 884 & 825 \\
\hline 97th & 677 & 809 & 978 & 905 & 964 & 1169 & 1150 & 1099 \\
\hline
\end{tabular}

Our results showed a significant association between serum cortisol and the lowest blood pressure registered in the immediate postnatal period. This correlation was independent of gestational age and birth weight. In addition, comparison of the pituitary-adrenal responses of group 1 and group 2 infants during the first and second week of life provided evidence that differential maturation of endocrine centres within the HPA axis could influence the regulation of systemic blood pressure in VLBW infants. Group 2 infants were significantly less mature and more sick than infants of group 1 (table 1). Despite their lower gestations, ACTH responses on days 7 and 14 were increased significantly compared with group l patients (fig 2), suggesting that the pituitary centre reacted vigorously to exogenous stress and was probably functionally mature at an early stage of human development. In contrast, poor cortisol response in the presence of severe hypotension and raised plasma ACTH concentration on day 7 signified adrenal hyporesponsiveness of group 2 infants during the first week of life (fig 3). However, circulating cortisol concentrations had increased substantially by the end of the second week and represented a significant improvement in adrenal function at this stage (fig 3). Moreover, significant positive correlations of plasma ACTH on days 7 and 14 with the use of inotropes and volume expanders, together with negative associations of serum cortisol on day 7 with these indices, lent further support to the hypothesis that the primary site of endocrine dysfunction was located at the adrenal cortex. Thus, the overall endocrine findings suggested normal or enhanced pituitary response but transient inability of the adrenals to maintain cortisol homoeostasis in premature newborns in the immediate postnatal period-a phenomenon that could be referred to as transient adrenocortical insufficiency of prematurity or TAP. The adrenocortical component of this condition has been previous described by us ${ }^{14} 26$ and other research workers. ${ }^{10-1427-31}$ The present prospective study serves to illustrate the important association between serum cortisol and blood pressure, and in addition, to characterise the transient nature and other primary endocrinological features of this phenomenon. Although one could argue that the hCRH tests performed on day 7 may not necessarily reflect the condition of the infants in the earlier days, this assumption would only be valid if the HPA axis were mature and responsive. The scenario, however, would not apply to infants with adrenocortical insufficiency lasting for the entire first week of life. Further, it would not be feasible, in most cases, to perform an elaborated stimulation test in sick hypotensive infants at the acute stage. More importantly, we have achieved the objective by showing a suboptimal adrenal response within early postnatal life in a targeted group of patients who were hypotensive and requiring high dose inotrope treatment.

The endocrine expression of TAP corresponded closely to its clinical manifestations in that hypotension in the early postnatal period occurred most commonly in extremely premature infants, presented within the first week of life, and responded readily to a short course of corticosteroids. ${ }^{10-14}$ As opposed to hypotension secondary to hypovolaemia and myocardial dysfunction, TAP induced hypotension has been characterised by its resistance to conventional inotrope treatment and volume expansion, and also by its prompt and efficient response to corticosteroids. ${ }^{10-14}$ The mechanisms by which corticosteroids facilitate an improvement in systemic blood pressure have not been fully elucidated. It has been shown in animal studies that corticosteroids are able to increase the density of $\beta$ adrenergic receptors within a few hours of drug administration, ${ }^{32-34}$ and to reverse the desensitisation effect of prolonged catecholamine exposure on the receptors. ${ }^{32}{ }^{35}$ Corticosteroids could also increase expression of the angiotensin 2 (type 1) receptor gene of the myocardium. ${ }^{36}$ Both actions could enhance cardiovascular responsiveness to endogenous or exogenous catecholamines, and result in a rapid upsurge of systemic blood pressure. In this study, we also estimated the time of adrenal recovery by performing two hCRH tests in quick succession. Our results suggest that, in most cases, adrenal recovery from TAP occurred early, and circulating cortisol

Table 5 Comparison of sensitivity, specificity, and positive and negative predictive values of different centile cut off values for serum cortisol concentration (nmol/l; indicated in parentheses) for diagnosis of early hypotension in very low birthweight infants

\begin{tabular}{|c|c|c|c|c|c|c|c|c|}
\hline & \multicolumn{2}{|c|}{ 25th centile } & \multicolumn{2}{|c|}{ 50th centile } & \multicolumn{2}{|c|}{ 75th centile } & \multicolumn{2}{|c|}{ 90th centile } \\
\hline & $\begin{array}{l}0 \text { min } \\
(\leqslant 115)\end{array}$ & $\begin{array}{l}30 \text { min } \\
(\leqslant 261)\end{array}$ & $\begin{array}{l}0 \min \\
(\leqslant 198)\end{array}$ & $\begin{array}{l}30 \min \\
(\leqslant 384)\end{array}$ & $\begin{array}{l}0 \min \\
(\leqslant 343)\end{array}$ & $\begin{array}{l}30 \text { min } \\
(\leqslant 564)\end{array}$ & $\begin{array}{l}0 \min \\
(\leqslant 560)\end{array}$ & $\begin{array}{l}30 \text { min } \\
(\leqslant 797)\end{array}$ \\
\hline Sensitivity & 0.23 & 0.27 & 0.47 & 0.29 & 0.77 & 0.76 & 0.92 & 0.96 \\
\hline Specificity & 0.91 & 0.93 & 0.80 & 0.93 & 0.43 & 0.50 & 0.27 & 0.23 \\
\hline PPV & 0.82 & 0.88 & 0.81 & 0.89 & 0.71 & 0.73 & 0.70 & 0.69 \\
\hline NPV & 0.40 & 0.41 & 0.46 & 0.42 & 0.51 & 0.54 & 0.67 & 0.77 \\
\hline
\end{tabular}


concentrations at day 14 seemed to be adequate to maintain a satisfactory blood pressure without the need for further inotropic support (table 1) or continuous corticosteroid replacement. ${ }^{11-14}$ Thus, the transient nature of TAP may be attributed to deficiency of intermediate enzymes of cortisol synthesis, 27283031 probably secondary to adrenocortical immaturity of preterm infants and radical remodelling of the adrenal cortex during the immediate postnatal period ${ }^{37}$ Nonetheless, it is possible that this transient period may be prolonged in a proportion of extremely low birthweight infants. A recent study suggested that some of these infants had low serum cortisol and raised cortisol precursors between days 15 and 19 of postnatal life. ${ }^{31}$ However, such findings require further confirmation, as the sample size of the study was relatively small, some infants had already received corticosteroids before the ACTH stimulation test, and recovery of adrenal function tended to lag behind that of the pituitary.

This study also provides the centile distribution of serum cortisol for VLBW infants with normal blood pressure and hypotensive patients requiring inotropic support (tables 3 and 4). These centile tables should allow better statistical and clinical interpretation of the hormone concentrations in relation to blood pressure in the early postnatal period. Because of the overlap in serum cortisol between the two groups, it is difficult to determine with confidence at what circulating cortisol concentration the patients will suffer from adrenocortical insufficiency. The reasons are: (a) newborns with different gestations may have different "normal" circulating levels; (b) "normal" serum cortisol tends to decrease naturally with increasing postnatal age during the first few weeks of life ${ }^{38}{ }^{39} ;(c)$ the presumed adequate cortisol concentration in infants with normal blood pressure may not be sufficient to sustain cardiovascular homoeostasis in critically ill or highly stressed patients. Such limitations in data interpretation are unavoidable because of the complex nature of factors that influence the HPA response. We have sought to overcome some of these problems by standardising the time for performing the hCRH tests. Further, it is arguable that the studied infants may represent a sicker category of patients, as all required arterial line monitoring soon after birth. The more or less equal distribution of infants between the normal blood pressure group (group 1; 43\%) and the hypotensive group (group 2; $57 \%$ ) suggests that a wide spectrum of VLBW infants with normal and abnormal blood pressure were studied. Our results indicate that the 25th and 50th centile basal and peak serum cortisol concentrations in hypotensive patients on day 7 correspond closely to the 3rd and 10th25 th centile concentrations in infants with normal blood pressure respectively (table 3 ). These values represent low circulating cortisol concentrations in highly stressed patients. ${ }^{29}$ In fact, the range of unstimulated serum cortisol (73-562 nmol/l) in uncomplicated preterm infants described by Heckmann and coworkers ${ }^{40}$ correlates closely with the basal serum cortisol of our infants in group 1, and falls between the 3rd and 90th centiles (table 3).

The same group of investigators in a subsequent study further showed that circulating serum cortisol concentrations in hypotensive preterm infants requiring inotropes were significantly lower than those of uncomplicated preterm infants as well as ill preterm infants who did not require inotropic support. ${ }^{41}$ Similarly, the range of unstimulated serum cortisol in hypotensive patients requiring inotropes $(41-378 \mathrm{nmol} / \mathrm{l})$ is similar to that of our infants in group 2 (3rd-90th centiles; table 3). Thus, the centile tables in this study correlate well with other published results, ${ }^{40}{ }^{41}$ but, in addition, show the stimulated hormone concentrations and the dynamic changes in the pituitary-adrenal response in the first two weeks of life. Further, the serum cortisol concentrations were found to have high specificities and positive predictive values (0.80-0.93 and $0.81-0.89$ respectively), but relatively low sensitivities and negative predictive values (0.23-0.49 and 0.40-0.46 respectively; table 5) for diagnosing early neonatal hypotension. As the diagnostic accuracy was similar for the basal and peak cortisol concentrations (table 5), the morning basal hormone concentration could probably provide a reasonable assessment of adrenal function, making it unnecessary to perform an elaborated hCRH stimulation test in sick hypotensive infants.

In the early postnatal period, the "physiological" adrenocortical response of animals to stress is greatly reduced. This period of adrenocortical quiescence appears to be beneficial to the growth and development of the central nervous system by counteracting the influence of excessive glucocorticoids on inhibition of neural cell division and neuronal myelination. ${ }^{42}$ Although the presence of severe systemic hypotension with low serum cortisol should alert neonatal clinicians to consider TAP, corticosteroid replacement therapy must be used with caution. It is likely that only a small physiological dose and a short course of corticosteroids would be required to support the blood pressure, as recovery of adrenocortical responsiveness has been shown to be prompt and substantial. ${ }^{11-14}$ Thus, further randomised control studies are required to determine the benefits and adverse effects of corticosteroid treatment in TAP.

In summary, we have assessed the pituitary-adrenal response in a large series of VLBW infants. Our findings further characterise the fundamental endocrinological abnormalities of TAP: normal or exaggerated pituitary response; adrenocortical insufficiency; good recovery of adrenal function in most cases by day 14 of postnatal life. To our knowledge, this is the first prospective study to assess the pituitary reserve and the timing of adrenal recovery in the immediate postnatal period, and also to show a significant association between serum cortisol and blood pressure in preterm hypotensive infants. The centile distribution of serum cortisol for normotensive and hypotensive infants may provide a guide for neonatal clinicians and paediatric endocrinologists for better interpretation of the circulating hormone concentrations in relation to blood pressure during the first and second week of life. The basal cortisol concentration gives a reliable assessment of the adrenocortical status and could probably be used instead of the elaborated hCRH test for evaluation of hypocortisolism. A short course of a physiological dose of corticosteroids could be considered in VLBW infants with refractory hypotension and low serum cortisol. Until the beneficial and adverse effects of corticosteroid replacement have been properly assessed, this modality of treatment should be used with caution.

\section{Authors' affiliations \\ P C Ng, C H Lee, K C Ma, T F Fok, Department of Paediatrics, Prince of Wales Hospital, Chinese University of Hong Kong \\ C W K Lam, I H S Chan, Department of Chemical Pathology, Prince of Wales Hospital \\ E Wong, Centre for Clinical Trials and Epidemiological Research, Prince of Wales Hospital}

\section{REFERENCES}

1 Plady SP, Wodey E, Betremieux P, et al. Effects of volume expansion on cardiac output in the preterm infant. Acta Paediatr 1997;86:1241-5.

2 Gill $A B$, Weindling $A M$. Echocardiographic assessment of cardiac function in shocked very low birthweight infants. Arch Dis Child 1993;68:17-21.

3 Greenough A. Use and misuse of albumin infusions in neonatal care. Eur J Pediatr 1998;157:699-702.

4 Bauer K, Linderkamp O, Versmold HT. Systolic blood pressure and blood volume in preterm infants. Arch Dis Child 1993;69:521-2. 
5 Miall-Allen VM, De Vries LS, Dubowitz LMS, et al. Blood pressure fluctuation and intraventricular hemorrhage in the preterm infant of less than 31 weeks gestation. Pediatrics 1989;83:657-61

6 Goldstein RF, Thompson RJ Jr, Oehler JM, et al. Influence of acidosis, hypoxemia and hypotension on neurodevelopmental outcome in very low birth weight infants. Pediatrics 1995;95:238-43.

7 Murphy DJ, Hope PL, Johnson A. Neonatal risk factors for cerebral palsy in very preterm babies: case-control study. BMJ 1997;314:404-8.

8 So KW, Fok TF, Ng PC, et al. Randomised controlled trial of colloid or crystalloid in hypotensive preterm infants. Arch Dis Child Fetal Neonatal Ed 1997;76:F43-6.

9 Klarr JM, Faix RG, Pryce CJ, et al. Randomized, blind trial of dopamine versus dobutamine for treatment of hypotension in preterm infants with respiratory distress syndrome. J Pediatr 1994; 125:117-22.

10 Colasurdo MA, Hanna CE, Gilhoody JT. Hydrocortisone replacement in extremely premature infants with cortisol insufficiency [abstract]. Clin Res 1989:37:180A

11 Helbock HJ, Insoft RM, Conte FA. Glucocorticoid-responsive hypotension in extremely low birth weight newborns. Pediatrics 1993;92:715-16.

12 Fauser A, Pohlandt F, Bartmann P, et al. Rapid increase of blood pressure in extremely low birth weight infants after a single dose of dexamethasone. Eur J Pediatr 1993;152:354-6.

13 Gaissmaier RE, Pohlandt F. Single-dose dexamethasone treatment of hypotension in preterm infants. J Pediatr 1999;134:701-5.

$14 \mathrm{Ng} \mathrm{PC}$, Lam CWK, Fok TF, et al. Refractory hypotension in preterm infants with adrenocortical insufficency. Arch Dis Child Fetal Neonatal Ed 2001;84:F122-4.

$15 \mathrm{Ng}$ PC, Lam CWK, Lee $\mathrm{CH}$, et al. Reference ranges and factors affecting the hCRH test in preterm, very low birth weight infants. J Clin Endocrinol Metab 2002;87:4621-8.

16 Ment LR, Oh W, Ehrenkranz RA, et al. Low-dose indomethacin and prevention of intraventricular haemorrhage: a multicenter randomized trial. Pediatrics 1994;93:543-50.

17 Ballard JL, Khoury JC, Wedig K, et al. New Ballard score, expanded to include extremely premature infants. J Pediatr 1991;119:417-23.

18 Report of a Joint Working Group of the British Association of Perinatal Medicine and the Research Unit of the Royal College of Physicians. Development of audit measures and guidelines for good practice in the management of neonatal respiratory distress syndrome. Arch Dis Child 1992;67:1221-7.

19 Lee J, Rajadurai VS, Tan KW. Blood pressure standards for very low birthweight infants during the first day of life. Arch Dis Child Fetal Neonatal Ed 1999;81:F168-70.

$20 \mathrm{Ng}$ PC, Wong GWK, Lam CWK, et al. The pituitary-adrenal responses to exogenous human corticotropin-releasing hormone in preterm, very low birth weight infants. J Clin Endocrinol Metab 1997;82:797-9.

21 Karlsson R, Kallio J, Irjala K, et al. Adrenocorticotropin and corticotropinreleasing hormone tests in preterm infants. J Clin Endocrinol Metab 2000;85:4592-5

22 Yoder BA, Martin H, McCurnin DC, et al. Impaired urinary cortisol excretion and early cardiopulmonary dysfunction in immature baboons. Pediatr Res 2002;51:426-32
23 Tantivit P, Subramanian N, Garg M, et al. Low plasma cortisol in term infants with refractory hypotension [abstract]. Pediatr Res 1997;41:A1076.

24 Scott SM, Watterberg KL. Effect of gestational age, postnatal age, and illness on plasma cortisol concentrations in premature infants. Pediatr Res 1995:37:112-16.

25 Bourchier D, Weston PJ. Randomised trial of dopamine compared with hydrocortisone for the treatment of hypotensive very low birthweight infants. Arch Dis Child Fetal Neonatal Ed 1997;76:F174-8.

$26 \mathrm{Ng}$ PC, Wong GWK, Lam CWK, et al. Pituitary-adrenal response in preterm, very low birth weight infants after treatment with antenatal corticosteroids. J Clin Endocrinol Metab 1997;82:3548-52.

27 Hingre RV, Gross SJ, Hingre KS, et al. Adrenal steroidogenesis in very low birth weight preterm infants. J Clin Endocrinol Metab 1994;78:266-70.

28 Lee MM, Rajagopalan L, Berg GJ, et al. Serum adrenal steroid concentrations in premature infants. J Clin Endocrinol Metab 1989;69:1133-6.

29 Korte C, Styne D, Merritt TA, et al. Adrenocortical function in the very low birth weight infant: improved testing sensitivity and association with neonatal outcome. J Pediatr 1996;128:257-63.

30 Huysman MWA, Hokken-Koelega ACS, De Ridder MAJ, et al. Adrenal function in sick very preterm infants. Pediatr Res 2000;48:629-33.

31 Watterberg KL, Gerdes JS, Cook KL. Impaired glucocorticoid synthesis in premature infants developing chronic lung disease. Pediatr Res 2001:50:190-5

32 Davies AO, Lefkowitz RJ. Corticosteroid-induced differential regulation of $\beta$ adrenergic receptors in circulating human polymorphonuclear leukocytes and mononuclear leukocytes. J Clin Endocrinol Metab 1980;51:599-605.

33 Mano K, Akbarzadeh A Townley RG. Effect of hydrocortisone on $\beta$ adrenergic receptors in lung membranes. Life Sci 1979;25:1925-30.

34 Brodde OE, Michel MC, Gordon EP, et al. $\beta$-adrenoceptor regulation in the human heart: can it be monitored in circulating lymphocytes. Eur Heart $J$ 1989:10(suppl B):2-10.

35 Hui KK, Conolly ME, Tashkin DP. Reversal of human lymphocyte $\beta$ adrenoceptor desensitization by glucocorticoids. Clin Pharmacol Ther 1982;32:566-71

36 Segar JL, Bedell K, Page WV, et al. Effect of cortisol on gene expression of the renin-angiotensin system in fetal sleep. Pediatr Res 1995;37:741-6.

$37 \mathrm{Ng} \mathrm{PC}$. The fetal and neonatal hypothalamic-pituitary-adrenal axis. Arch Dis Child Fetal Neonatal Ed 2000;82:F250-4.

38 Wittekind CA, Arnold JD, Leslie Gl, et al. Longitudinal study of plasma ACTH and cortisol in very low birth weight infants in the first 8 week of life. Early Hum Dev 1993;33:191-200.

39 Saedi SA, Dean H, Dent W, et al. Reference ranges for serum cortisol and 17-hydroxyprogesterone levels in preterm infants. J Pediatr 1995; 126:985-7.

40 Heckmann M, Wudy SA, Haack D, et al. Reference range for serum cortisol in well preterm infants. Arch Dis Child Fetal Neonatal Ed 1999;81:F171-4.

41 Heckmann M, Wudy SA, Haack D, et al. Serum cortisol concentrations in ill preterm infants less than 30 weeks gestational age. Acta Paediatr 2000:89:1098-103.

42 Sapolsky RM, Meaney MJ. Maturation of the adrenocortical stress response: Neuroendocrine control mechanisms and the stress hyporesponsive period. Brain Res Rev 1986;11:65-76. 